\title{
ОЦЕНКА МУТАГЕННОЙ АКТИВНОСТИ ЛЕКАРСТВЕННОГО СРЕДСТВА ДЛЯ ЛЕЧЕНИЯ НАРУШЕНИЙ МОЗГОВОГО КРОВООБРАЩЕНИЯ НА ОСНОВЕ ПРОИЗВОДНОГО ХИНАЗОЛИНА
}

\author{
Д.А. Кавалерова', Г.Л. Снигур', С.С. Сурин', А.А. Озеров² \\ ФГБОУ ВО ВолгГМУ Минздрава России, кафедра биологии1, \\ кафедра фармацевтической и токсикологической химии2, \\ 400131 Российская Федерация Волгоград, площадь Павших Борцов, 1.
}

DOI: 10.19163/MedChemRussia2021-2021-491

Email: dareznikova@yandex.ru

Целью работы являлось определение мутагенного потенциала 3-[2-оксо-2-[(4-метоксифенил)амино]этил]хиназолин-4(3Н)-она в виде фармацевтической субстанции (ФС) готовой лекарственной формы (ГЛФ) в тестах invitro и invivo.

При изучении мутагенной активности в тесте invitro на индукцию генных мутаций (тест Эймса) изучались ФС и ГЛФ в концентрациях: 0,039063 мг/ мл, 0,078125 мг/мл, 0,15625 мг/мл, 0,3125 мг/мл, 0,625 мг/мл и 1,25 мг/мл. Для выявления мутагенного потенциала +S9/-S9 печени были использованы S.typhimurium TA98, TA100, TA1535, TA1537 и E.coli WP2 uvrA + WP2 [pKM101] для регистрации мутаций по типу замены пар оснований и сдвига рамки считывания [2]. Цитогенетическое исследование на индукцию хромосомных аберраций было проведено в двух сериях: однократное введение ФС и ГЛФ (самцы в терапевтической - 10,9 мг/кг, и субтоксической дозах - 500 мг/кг) и курсовое введение ФС и ГЛФ (самцы и самки в терапевтической дозе - 10,9 мг/кг). Позитивным контролем выступал мутаген (циклофосфамид - 20 мг/кг), негативным контролем 0,9\% раствор натрия хлорида [1].

В тесте на индукцию генных мутаций (тест Эймса) под действием ФС и ГЛФ по сравнению с негативным контролем не происходило статистически значимого увеличения ревертантных колоний. В цитогенетическом исследовании при введении ФС и ГЛФ в терапевтической и субтоксической дозах не выявлялось значимого увеличения уровня хромосомных аберраций. Результаты исследования по влиянию ФС и ГЛФ на индукцию генных мутаций в тесте Эймса и хромосомных аберраций в цитогенетическом тесте могут свидетельствовать об отсутствии мутагенной активности у лекарственного средства для лечения нарушений мозгового кровообращения на основе производного хиназолина.

\section{Литература:}

[1]. А.Н.Миронов, руководство по проведению доклинических исследований лекарственных средств. Часть первая-М: Гриф и К, 2012. С.80-93.

[2]. Ames MPFTM Penta I Xenometrix, Швейцария, Инструкция по применению теста Эймса в микропланшетном формате версия набора с полутвердыми стоками штаммов. Версия 4.5_S, 2012, 37 с. 